\title{
XEROFOTIC MOVEMENTS IN LEAVES
}

\author{
FrANK C. GATES
}

\section{(WITH EIGHT FIGURES)}

Definition.-The word xerofotic, expressing the ideas of dryness and light, gives a clue to the meaning the word is intended to connotate, namely, dryness caused by light. Xerofotic movements, therefore, are paratonic movements resulting from certain drying effects produced through the action of light. They are manifested by an upward bend in the leaflets or a curling or rolling upward of the blade.

Mechanism.- The side of a structure facing the sun becomes warmer than the opposite side. Under these conditions, other things being equal, there is a relatively greater loss of water from the exposed side. When the water is not replenished as fast as it evaporates, a greater lowering of the turgidity in the cells of the upper side ensues. The greater pressure exercised by the more turgid cells of the lower side causes the structure to bend or roll in the direction of the exposure. In the case of the most conspicuous examples, the leaflets of leguminous plants, the result of this action of light is an upward movement of the leaflets. The base of the leaflet is the seat of the differential turgidity.

No amount of heat or rapid transpiration is sufficient to cause the xerofotic movement unless there is also a difference in turgidity caused by one-sided illumination. This movement is entirely distinct from the collapse or wilting caused by too great a drying, and from the photeolic, or so-called sleep, movements.

Classification.-Two kinds of xerofotic response were observed: the localized response, in which the differential turgidity is largely confined to a small region, as, for example, the pulvini of leguminous leaflets; and the generalized response, in which the differential turgidity is spread over the leaf, causing the blade to curl or roll upward. Cases in which the leaves roll downward or underneath must be considered as wilting and not as xerofotic. responses.

399]

[Botanical Gazette, vol. 6I 
OCCURRENCE.-Examples of the generalized response were noted in the monocotyledonous families Poaceae, Araceae, Marantaceae, and Zingiberaceae. At different times the leaves might be rolled in either direction. Whenever the rolling is upward it should be considered as a xerofotic response, when downward, the result of wilting. Examples of the localized response, with which this article deals, were furnished by all the Leguminosae under observation. Such response is not limited to this family, however,

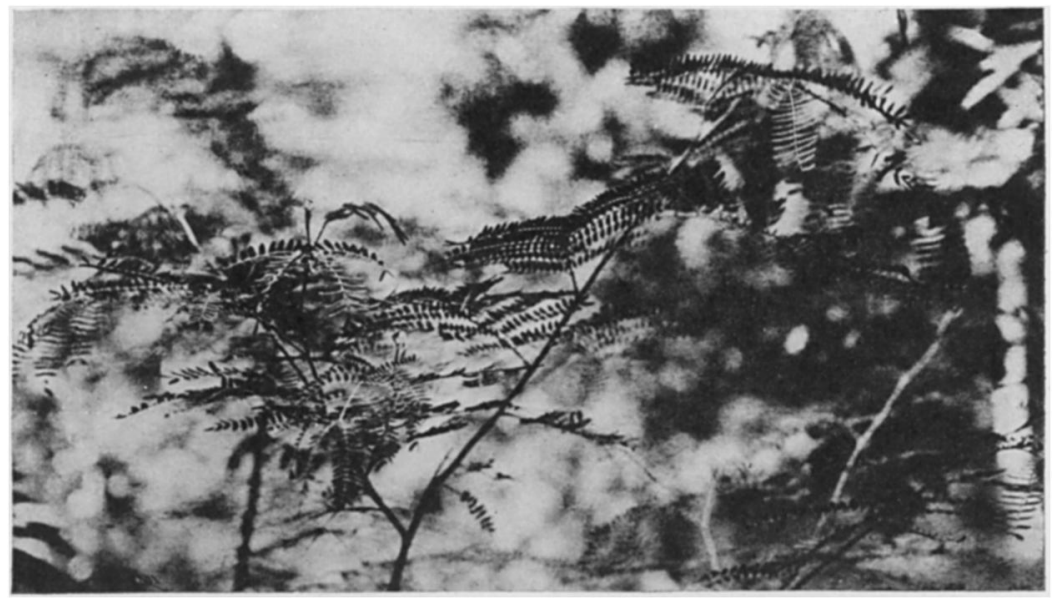

Fig. I.-Leucaena glauca, showing leaflets in the horizontal position, the normal day position; Los Baños, P.I., July I8, I914.

but is shown by Ipomoea Pes-caprae of the Convolvulaceae, and as well in a few other families of plants, particularly those whose species have compound leaves, as in the Meliaceae and Oxalidaceae. While xerofotic responses were noted also in Abrus precatorius, Acacia farnesiana, Aeschynomene indica, Albiszia procera, Bauhinia malabirica, Bauhinia sp., Caesalpinia pulcherrima, Canavalia ensiformis, C. lineata, Clitorea ternata, Delonix regia, Derris elliptica, Desmodium gangeticum, D. laxiflorum, D. pseudotriquetrum, D. triflorum, Enterolobium saman, Erythrina indica, Mezoneurum glabrum, Mucuna nigricans, M. longipedunculata, Pithecolobium dulce, $P$. subacutum, Pterocarpus indicus, Sesbania grandiflora, S. cannabina, Tamarindus indica, Teramnus labialis, Vigna lutea, 
and Voandseia subterranea, all belonging to the Leguminosae, the following were selected for study on account of their suitability and convenience: Gliricidia sepium of the subfamily Papilionatae, and Leucaena glauca and Mimosa pudica of the subfamily Mimosatae.

Amount of movement.-As the normal day position of the leaflets of legumes is a plane at approximately right angles to the light, the amount of movement can easily be expressed as

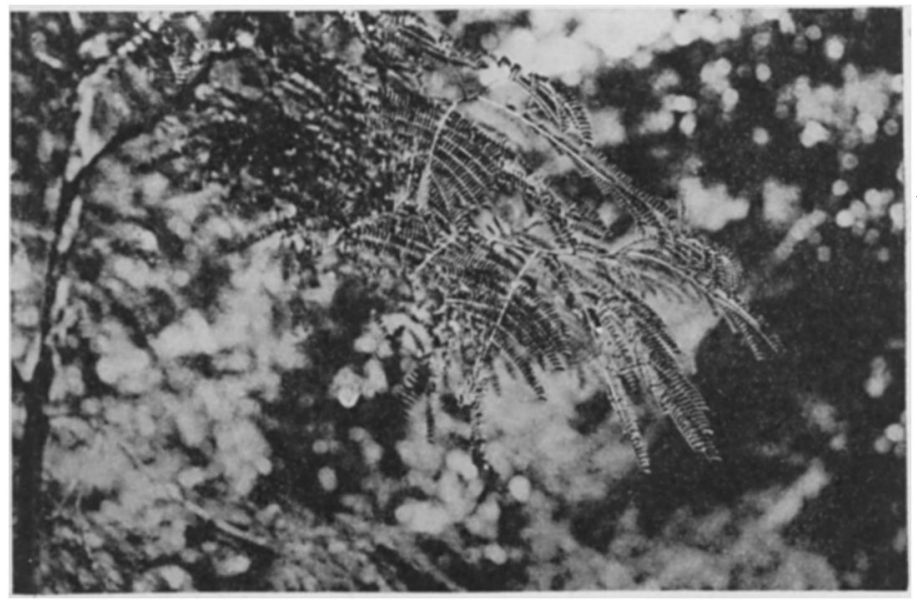

Fig. 2.-Leucaena glanca, showing leaflets in the xerofotic position, assumed under stimulation of direct sunlight; Los Baños, P.I., July 29, I9I4.

the amount of divergence from the horizontal. Whether the night position of the leaflets is erect or drooping, the xerofotic position is between $45^{\circ}$ and $70^{\circ}$ above the horizontal (figs. I and 2 ). When the night position of the leaflet is above the horizontal, as is the case with many members of the Mimosatae, the xerofotic position differs in not exceeding $70^{\circ}$ above the horizontal and in the absence of a forward movement often a part of the photeolic response. The horizontal position is assumed always between the xerofotic and the night positions.

INEQUALITY AND IRREGULARITY OF THE MOVEMENT.-Generally speaking, the upward bend is equal in each leaflet of a pair and likewise in a series of pairs. The exceptions noted in nature and 
produced by experiment make the general nature of the phenomenon clearer. As the intensity of the sun in the east increases, the west leaflets of a leaf, oriented north and south, usually exhibit the xerofotic movement before the east leaflets. It was demonstrated experimentally that in this response the paired condition of the leaflets is of less importance than in other movements. Even in the very sensitive Mimosa pudica, one leaflet of a pair is frequently bent more in xerofotic response than the other; while

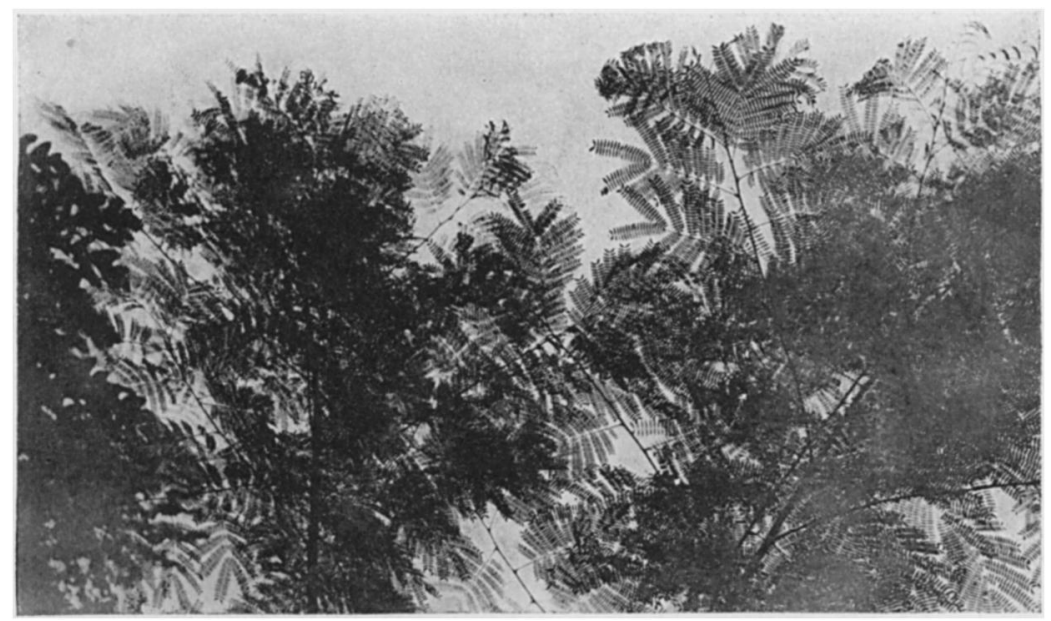

FIG. 3.-Lencaena glauca against the sky, showing amount of light cut off by leaflets in the horizontal position; compare with fig. 4; Los Baños, P.I., July 29, I9r4.

in the disturbance of turgidity caused by shock, the pairs act equally and simultaneously. This suggests that xerofotic conditions of unequal turgidity are very little, if at all, transmitted. All the leaflets of a compound leaf do not necessarily respond equally. Sometimes there is an obvious reason, for the basal leaflets are shaded. In other cases, only the hypothesis that the the basal leaflets are better and more quickly supplied with water to equalize the turgidity seems to explain the discrepancies in movement.

SeAsonal Relations.-This movement is not peculiar to any season, but is present throughout the year. In the dry season the xerofotic position is regularly assumed a short time after the sun 
has been shining directly on the leaflet. In exposed plants the movement is nearly certain to have taken place by $8: 30$ in the

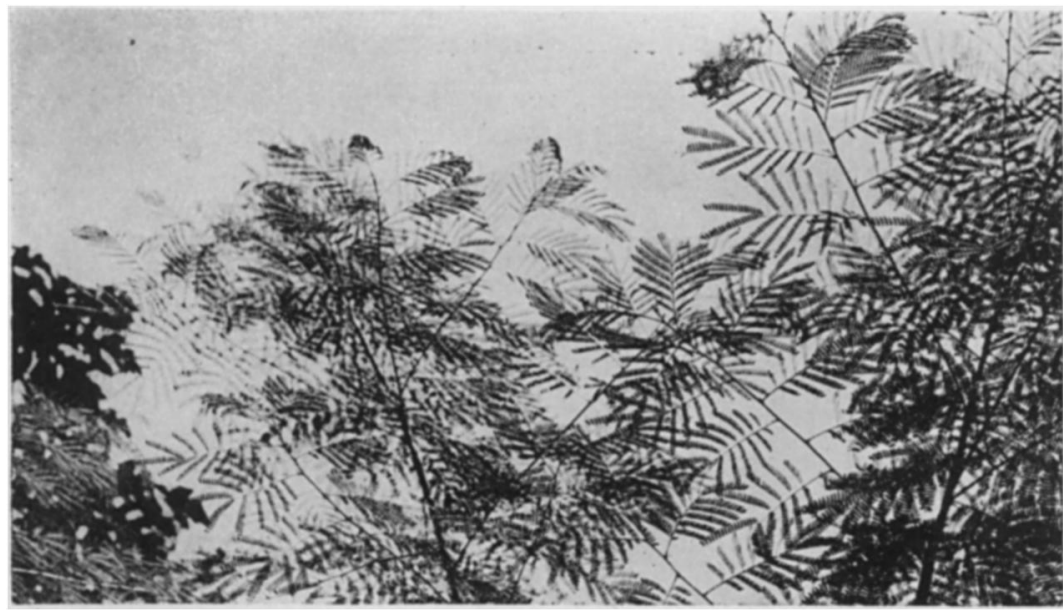

Fig. 4.-Lencaena glauca against the sky, showing amount of light cut off by leaflets in the xerofotic position; compare with fig. 3; Los Baños, P.I., July 29, I914.

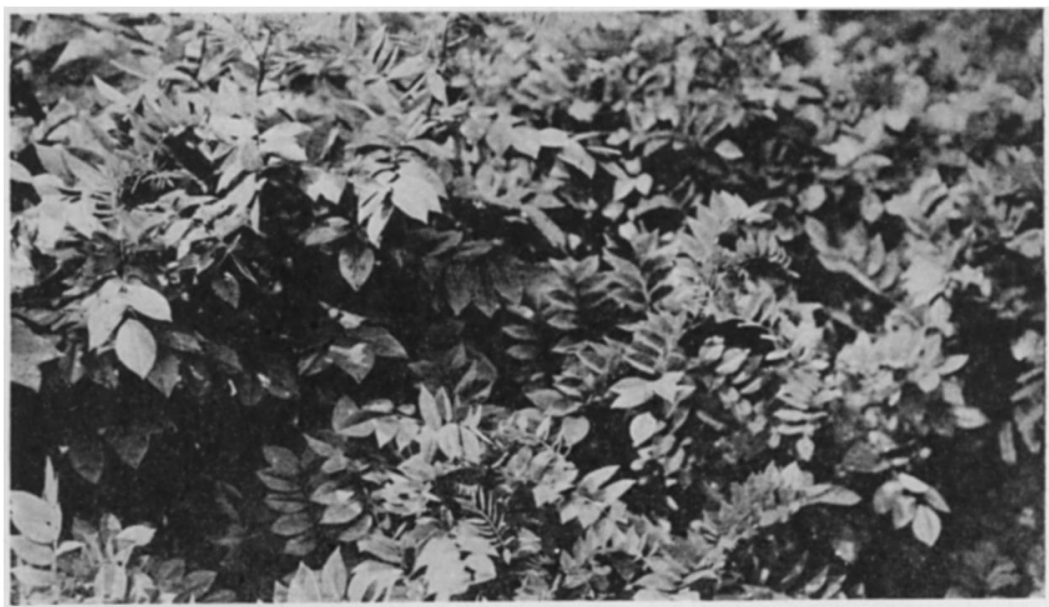

FIG. 5.-Gliricidia sepium shortly after a rain; the majority of the leaflets are in the horizontal position; a few in the upper and in the right-hand part of the figure are resuming the xerofotic position; Los Baños, P.I., July 20, 19I4.

morning. During the rainy season, since the sun is out less, the assumption of the xerofotic position is less frequent. 
RESUlTS AND ADVANTAGES.-The obvious result of the xerofotic position is to decrease the amount of direct radiant energy received per unit area of leaf. This reduces the harmfulness of too great sunlight upon the chlorophyll, as well as reducing the transpiration during the critical time of day. Its frequency is undoubtedly a valuable asset to the family Leguminosae, one of the most important plant families and the richest in species in the tropics.

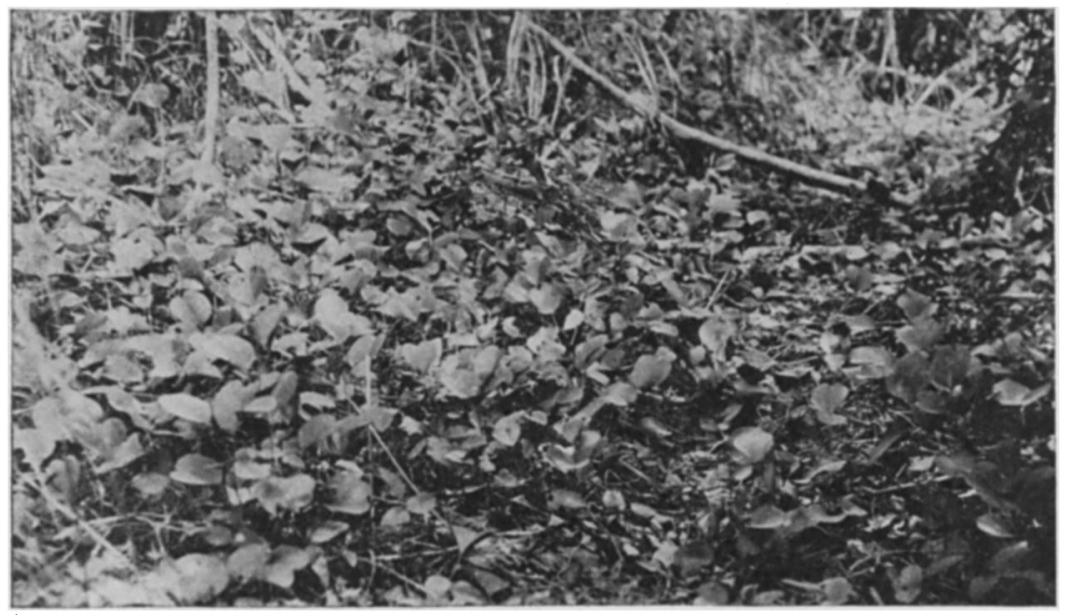

Fig. 6.-Ipomoea Pes-caprae growing in the shade, showing leaves in spread-out position; Taal Volcano, P.I., March 7, r9I 5.

The assumption of the xerofotic position permits a great deal more light to come through the leaf layer. This is admirably shown in figs. 3 and 4 of Leucaena glauca, taken on the same day from the same spot; fig. 3 when the leaflets were in the horizontal position; and fig. 4 three hours later, after the leaflets had assumed the xerofotic position.

EXPERIMENTATION.-That this class of movements might not rest solely on observation, a number of experiments were performed at Los Baños, Philippine Islands, during I9I3 and r9I4. Screens were interposed between the sun and plants of Gliricidia sepium, Leucaena glauca, and Mimosa pudica, whose leaflets were in the xerofotic position. In every case the leaflets fell back to the horizontal position. Occasionally as short a time as 5 minutes 
was sufficient to bring about the change, but usually it took about 20 minutes. Upon taking away the screen the xerofotic position was gradually resumed. When the sun was very hot a little upward curling of the outer end of the leaflet was noticed before the complete assumption of the xerofotic position.

While the screen experiments clearly indicated that drying effects dependent upon exposure to sunlight were fundamental, other experiments sought to produce drying effects independently

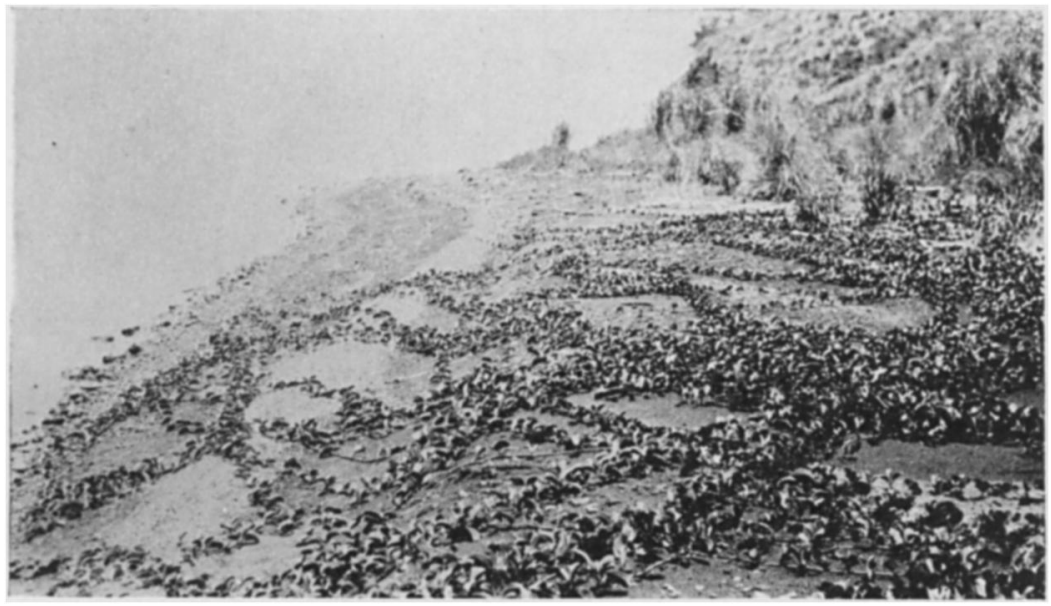

Fig. 7.-I I pomoea Pes-caprae growing on the open strand, showing leaves in the xerofotic position, assumed during the hours of strong sunlight; Taal Volcano, P.I., April 18, 1914.

of the sunlight. Two of the common laboratory drying agents, absolute alcohol and xylol, were employed. Several legumes were experimented with, but in the majority of cases, the delicateness of the rachis and the small size of the pulvinus made the experiments a failure. At length, however, a suitable plant was found in Gliricidia sepium, in which the leaflets, rachis, and pulvini are large and coarse (fig. 5). In successive experiments, both absolute alcohol and xylol were carefully applied to the upper side of the pulvinus with a small pointed brush. As the drying agent withdrew water locally from the upper cells of the pulvinus, the xerofotic position of the leaflet was gradually assumed. The experiments 
were conducted both out of doors and in the laboratory, with the leaf right side up and upside down. In each case the effect of the local withdrawal of water was the assumption of the xerofotic position.

In additional experiments, branches of trees were cut away so that shade leaves, in which no previous xerofotic movement had been noted, were exposed to the full sun. In all such cases the xerofotic position was soon taken. A burning-glass, used to intensify

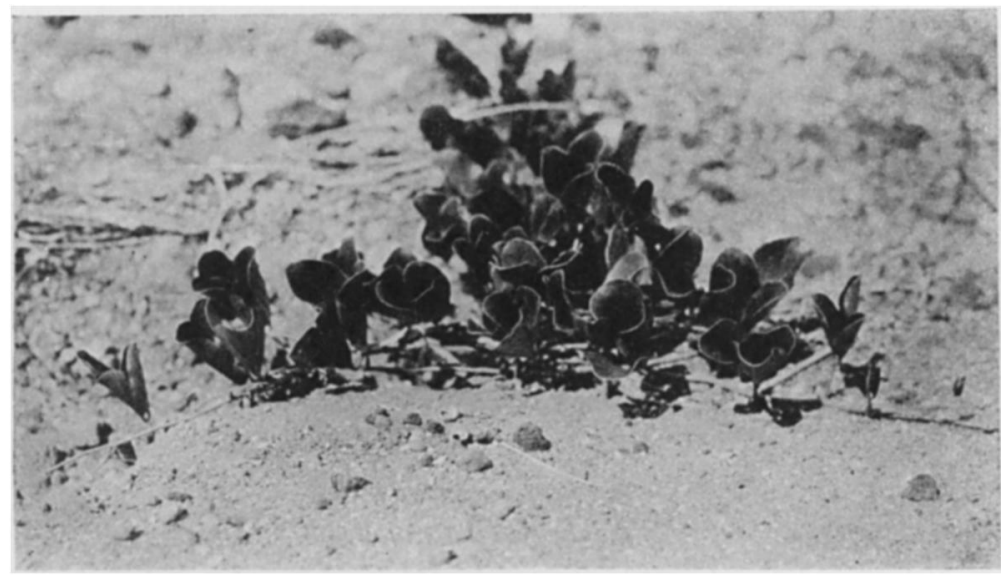

Fig. 8.-Canavalia lineata growing on the strand, showing leaflets in the xerofotic position; Taal Volcano, P.I., March 7, I9I 5.

the action of the sun on leaflets which had been artificially shaded, brought about a more rapid assumption of the xerofotic position.

Both shade and xylol experiments were conducted upon the convolvulaceous I pomoea Pes-caprae, growing on the strand of Taal Volcano, Philippine Islands (figs. 6. 7, and 8). In this case the clam-shaped simple leaf spread out under the dense shade of a screen and spread out leaves folded nearly together soon after xylol was applied to the upper part of the midrib.

\section{Summary}

I. Xerofotic movements are paratonic movements, caused by unequal drying effects in direct sunlight, manifested by an upward bend in leaflets or a curling upward of the blade. Greater turgor 
of the cells of the lower side causes a movement in the direction from which the desiccating energy comes. The xerofotic position decreases the amount of direct radiant energy received per unit area of leaf, reducing the harmful action of intense sunlight upon the chlorophyll as well as checking transpiration.

2. Two classes of xerofotic response were noted. In the localized type the differential turgidity acts in a limited region, such as in the pulvini of leguminous leaflets. In the generalized type the difference in turgidity is between the upper and lower part of the blade. The localized response was characteristic of all observed species of Leguminosae, but is not limited to that family. The generalized type was noted particularly in the monocotyledonous families Poaceae, Araceae, Marantaceae, and Zingiberaceae.

3. In nature the response was brought about by direct stimulation from the sun. It was artificially simulated by the action of the chemical desiccating agents, absolute alcohol and xylol, on Gliricidia sepium and Ipomoea Pes-caprae.

4. The amount of movement varied between $45^{\circ}$ and $70^{\circ}$ above the horizontal. Movement took place under suitable conditions at any season. The amount of response, even in leaflets of a pair, varied under different conditions of exposure.

Carthage College

Carthage, Ill. 